\title{
ANALISIS PERAN INDUSTRI RUMAH TANGGA (HOME INDUSTRY) PADA USAHA KERAJINAN KAIN PERCA TERHADAP PENDAPATAN KELUARGA (Studi Kualitatif di Desa Bulaksari - Sragen)
}

\author{
MICKY PRATHAMA ${ }^{1}$, OCTA NILAM LUKKITA AGA ${ }^{2}$ \\ micky.prathama@ibm.ac.id ${ }^{1}, \underline{\text { octanilam@ibm.ac.id }{ }^{2}}$

\section{Program Studi Ekonomi Pembangunan ${ }^{1}$, Program Studi Manajemen² Institut Bisnis Muhammadiyah Bekasi}

\begin{abstract}
ABSTRAK
Tujuan dari penelitian ini adalah untuk mengetahui perihal usaha kecil/ home industri kerajinan kain perca serta pendapatan keluarga di Kecamatan Sragen Kabupaten Sragen Jawa tengah. Jumlah populasi untuk penelitian ini adalah 280 orang. Untuk pengambilan sampelnya menggunakan teknik random sampling, yaitu memilih dan menentukan desa yang hendak diteliti, lalu masing-masing $10 \%$ dari populasi dengan pertimbangan bahwa di desa tersebut cukup banyak yang membuat kerajinan kain perca. Hasil analisis pada penelitian ini data diperoleh bahwa usaha kain perca memiliki peran dalam membantu pendapatan keluarga di Kecamatan Sragen Kabupaten Sragen Jawa Tengah. Penelitian ini sesuai dengan hasil pendapatan keluarga yang di bantu ibu rumah tangga dengan rata-rata. Hal ini menunjukkan bahwa pengelolaan home industry kerajinan kain perca sangat membantu pendapatan keluarga maka dari itu perlu dikembangkan usaha kain perca di Kabupaten Sragen.
\end{abstract}

Kata Kunci: Industri Ibu Rumah Tangga (home industry), Pendapatan Keluarga

\section{ABSTRACT}

The purpose of this study was to determine the small business/home industry of patchwork and family income in Sragen District, Sragen Regency, Central Java. The total population for this study was 280 people. For sampling, using random sampling technique, which is selecting and determining the village to be studied, then $10 \%$ of the population each with the consideration that in that village there are quite a lot of patchwork crafts. The results of the analysis in this study showed that the patchwork business has a role in helping family income in Sragen District, Sragen Regency, Central Java. This study is in accordance with the results offamily income assisted by housewives on average. This shows that the management of the patchwork home industry is very helpful for family income, therefore it is necessary to develop a patchwork business in Sragen Regency.

Keywords: Housewife Industry (home industry), Family Income 


\section{PENDAHULUAN}

Tujuan Pembangunan Nasional adalah mewujudkan suatu masyarakat yang adil dan makmur merata secara material dan spiritual telah di kemukakan dalam Garis-Garis Besar Haluan Negara berdasarkan Pancasila dan UUD 1945 dalam wadah Negara kesatuan Republik Indonesia yang merdeka dan berkedaulatan rakyat dalam lingkungan pergaulan dunia yang merdeka, bersahabat, tertib, dan damai.

Sebagai upaya meningkatkan perekonomian keluarga tidak bisa jika hanya bertumpu pada pendapatan kepala keluarga semata, tetapi juga perlu adanya sampingan pihak yang membantu dari pihak lain seperti anak dan istri. Selama ini sektor industri merupakan tumpuan harapan terbesar dalam upaya membangkitkan kembali ekonomi masyarakat. Hal itu disebabkan karena kuatnya pengaruh sektor ini terhadap sektor lainnya. Salah satu contoh nyata, sektor perdagangan sudah pasti akan turut mengalami lonjakan yang signifikan apabila sektor industrinya mengalami perkembangan. Selain itu sektor kerajinan yang dilakukan para ibu rumah tangga juga membutuhkan bahan baku dari sisa kain para penjahit atau konveksi, yang di dapat dengan secara cuma-cuma ada juga yang mendapatkan bahan baku dengan membelinya, karena sisa bahan baku dari pabrik di jual untuk meningkatkan ekonomi perusahaan, jadi semua bahan dari pabrik tidak ada yang di buang sia-sia.

Pembinaan home industri atau usaha kreatif rumah tangga merupakan salah satu langkah tepat sebagai solusi bagi permasalahan tenaga kerja perempuan di wilayah perdesaan. Menurut Prayitno, pengadaan industri kecil merupakan salah satu upaya untuk mendukung kegiatan pembangunan ekonomi di wilayah desa. Terutama untuk industri yang berkaitan dengan pengolahan hasil pertanian. Selain prospektif dalam hal ekonomi sehingga meningkatkan pendapatan masyarakat, keberadaan industri tersebut juga akan menjadi solusi bagi persoalan ketenagakerjaan. Sebab industri semacam itu akan menyerap banyak tenaga kerja lokal, dari masyarakat setempat.

Untuk industri rumah tangga di wilayah pedesaan, yang memiliki potensi besar selain pengolahan hasil pertanian adalah industri kecil kerajinan rakyat. Peran kedua yang menonjol dari home industry di pedesaan tersebut adalah sebagai penggerak roda mesin perekonomian di desa, mendukung perkembangan perdagangan dan pembangunan daerah. Oleh karena itulah potensi home industri penting untuk dihidupkan, digerakkan dan dikembangkan di tengah kehidupan ekonomi modern, supaya bisa mempunyai daya saing.

Pendirian home industri dimaksudkan sebagai salah satu upaya untuk peningkatan serta perbaikan struktur dari usaha yang masuk kategori industri kecil agar menjadi kuat dan memiliki kemampuan untuk tumbuh dengan cara meningkatkan peranan dalam berelasi dengan sektor industri lain. Maka dari itu, peran industri rumah tangga yang dijalankan oleh 
ibu-ibu rumah tangga di kawasan pedesaan perlu diberikan perhatian lebih besar serta dirangsang pertumbuhannya, sehingga bisa membuka peluang kerja dan mampu berdampak pada peningkatan pendapatan masyarakat.

Mayoritas industri rumah tangga (home industry) di Kecamatan Sragen, mempunyai kedekatan dengan masyarakat pedesaan, baik secara fisik, sosial, maupun ekonomi. Untuk contohnya yaitu, industri kerajinan kain perca yang banyak berdiri di Kecamatan Sragen, termasuk yang ada di Desa Bulak Sari-Sragen.

Home industry/ usaha rumahan kerajinan kain perca ini dimiliki dan dikelola oleh kebanyakan keluarga di daerah tersebut. Pelaksananya adalah para ibu rumah tangga. Keseluruhan aktivitas produksinya dikerjakan secara individu. Baik dalam tahap pencarian bahan baku, proses produksi, hingga pemasarannya. Prospek dari industri rumahan ini cukup bagus dan menjanjikan. Sebab bahan bakunya mudah didapat, yakni dari kain sisa penjahit atau konveksi.

\section{TINJAUAN PUSTAKA}

\section{Home Industry/Industri Rumah Tangga}

Home industry atau yang biasa dikenal dengan industri rumahan/ rumah tangga yaitu sebuah pekerjaan sekunder yang biasa dilakukan para ibu rumah tangga untuk mengisi waktu luang sehari-hari selain mengurus rumah tangga, mengurus anak, para ibu juga mencari kesibukan dan tujuannya untuk membantu suami demi keselarasan ekonomi di rumah tangga. Termasuk pada kegiatan kerajinan seperti yang dilakukan para ibu rumahan seperti pada penelitian ini yaitu membuat kerajinan kain perca (keset, tas, serbet, hiasan dinding, dll). Omset yang diperoleh para industry rumahan ini sangat lumayan karena dapat membantu pendapatan keluarga, selain mengisi waktu luang kegiatan membuat kerajinan ini dapat menjadi pekerjaan pokok karena hasilnya dapat digunakan sebagai penghasilan tambahan pada keluarga. Kegiatan ini seharusnya mendapatkan perhatian khusus bagi pemerintah sehingga kegiatan industry rumahan/ homeindustry dapat di kembangkan.

\section{Usaha Kecil Kerajinan Kain Perca}

Bahan baku yang digunakan pada kerajinan kain perca yaitu limbah dari sisa kain dari penjahit atau konveksi baik tergolong usaha kecil, menengah dan besar. Para pengrajin mengumpulkan sisa kain tersebut dibentuk menjadi sebuah karya yang indah dan mempunyai nilai jual.

Dengan cara memotong-motong kain sisa tersebut ke dalam bentuk dan ukuran tertentu sesuai kerajinan yang akan di buat. Tidak lupa juga dengan memadu padankan bentuk pola dan warna agar hasilnya bagus dan maksimal.

Hasil dari kerajinan kain perca menjadi sebuah karya yang banyak di kagumi dan di minati masyarakat. Pada mulanya kerajinan kain perca ini sebuah kerajinan tradisional yang jaman dahulu yang kurang diminati masyarakat tetapi sekarang malah 
menjadi trend dan digemari masyarakat, selain itu masyarakat juga minat karena sebagai kebutuhan seperti taplak meja, tas, hiasan dinding, dan lain-lain.

Pada dasarnya perca yaitu gabungan dari beberapa potongan kain kecilkecil sehingga menjadi sebuah hasil karya dengan bisa dengan cara dijahit baik dengan tangan maupun dengan mesin.

\section{Ibu Rumah Tangga}

Yaitu para ibu yang tidak mempunyai pekerjaan tetap. Aktivitas pokok mereka biasanya adalah mengurus rumah tangga, seperti antar jemput anak, mengurus rumah, dan tidak memiliki pekerjaan tetap. Dalam penelitian kali ini, yang dimaksud sebagai ibu rumah tangga ialah ibuibu yang memiliki kegiatan sampingan membuat kerajinan dari kain perca sehingga mempunyai nilai jual dan hasilnya di gemari para masyarakat. Jadi para ibu rumah tangga disini dapat membantu perekonomian keluarga walaupun pendapatannya tidak sebesar pendapatan suaminya. Para ibu rumah tangga sangat berperan terhadap pendapatan keluarga. Pada dasarnya kegiatan ini dilakukan untuk mengisi waktu luang tetapi dapat manfaat lain yaitu mendapatkan penghasilan.

\section{Alokasi Waktu Tenaga Kerja}

Responden dalam penelitian ini yaitu ibu rumah tangga yang kesehariannya membantu pekerjaan suaminya bekerja, ada yang bekerja bangunan, petani, dan serabutan. Pekerjaan membuat kerajinan dari waktu luang ibu rumah tangga setelah pekerjaan pokok di rumahnya selesai. Kegiatan membuat kerajinan kain perca, ibu rumah tangga mengerjakannya pada pagi hari sekitar jam 10.00 setelah mengantar anak sekolah sampai jam 12.00 wib waktu harus jemput anak sekolah, sore hari setelah bebenah rumah yaitu kisaran pukul 16.00 hingga 18.00 wib, serta malam hari setelah menyiapkan makan malam keluarga, yaitu pukul 21.00 hingga pukul 22.00 wib. Motivasi dari para ibu rumah tangga yang terlibat dalam kegiatan kerajinan kain perca ini ada yang niatnya untuk mengisi waktu luang, ada yang memang mencari nafkah, ada juga yang berniat ibadah.

\section{METODE PENELITIAN}

Pada penelitian kali ini, metode yang digunakan adalah metode kualitatif, yaitu metode penelitian yang biasa dipakai untuk penelitian-penelitian sosial dan dilaksanakan untuk sekelompok peneliti dalam bidang sosia.

Pada pelaksanaannya, pendekatan kualitatif yaitu dengan melakukan pengamatan terhadap objek penelitian dan melakukan interaksi dengan mereka. Hal itu dilakukan dalam rangka memahami serta menggali informasi atau data yang dibutuhkan oleh penelitian. Pendekatan kualitatif, ada beberapa istilah yang di gunakan untuk menunjuk subjek penelitian.

\section{PEMBAHASAN}

\section{Analisis Pembiayaan}

Pembiayaan kerajinan kain perca pada penelitian ini yaitu bahan baku yang biasa para ibu rumah tangga membeli dari penjahit, konveksi, atau 
pabrik baju dengan mengeluarkan uang sebesar Rp. 10.000/ karung tetapi ada juga penjahit yang tidak menjualnya tetapi langsung di kasih ke siapapun yang mau mengambilnya, bahan baku lainnya benang dan jarum Rp 15.000 untuk pemakaian sampai rusak, dan bensin yang digunakan untuk transportasi membeli bahan baku atau menjual hasil karyanya ke pameran atau di titip ke penjual kaki lima.

Selain pembiayaan yang sudah di sebutkan di atas yaitu seperti biaya tak terduga missal mesin jahit tibatiba rusak atau harus service.

\section{Analisis Pendapatan}

Pendapatan pada penelitian ini adalah pendapatan yang didapatkan oleh mereka, dalam hal ini para ibu rumah tangga yang terlibat dalam industri kecil kerajinan kain perca di wilayah yang menjadi lokasi penelitian. Pendapatan itu sendiri dibedakan menjadi dua, yakni pendapatan bersih dan pendapatan kotor.

\section{Hubungan tingkat pendapatan ibu rumah tangga terhadap pendapatan keluarga}

Home industri atau usaha rumah tangga dalam penelitian ini adalah usaha kerajinan kain perca yang berada di Desa Bulaksari, Kecamatan Sragen, Kabupaten Sragen . Tujuan dari penelitian adalah untuk mengetahui seberapa besar kegiatan para ibu rumah tangga ini dalam berkegiatan membuat kerajinan kain perca yang menurut para ibu rumah tangga penghasilannya lumayan untuk membantu pendapatan keluarga.

\section{Identitas Informan (tambah pertanyaan)}

Pelaku industri rumah tangga (home industry) yaitu masyarakat yang ada di desa Bulaksari Kecamatan Sragen. Pelaku industri rumah tangga ini ada yang sudah menjalankan usahanya dari 3-10 tahun. Kebanyakan ibu rumah tangga membuat kerajinan kain perca di rumah masing-masing karena bisa mengerjakan pekerjaan rumah dan mengurus anak. Maka informan pada penelitian ini adalah orang yang terlibat langsung atau orang yang membuat kerajinan kain perca tersebut.

Adapun gambaran umum identitas informan dalam penelitian ini yaitu:

1. Informan 1

Ibu Suliyem adalah seorang pengrajin kain perca di Desa Bulaksari Rt 01/ Rw 08 Kecamatan Sragen, usia ibu Suliyem 48 tahun beragama islam, pendidikan terakhir SMP. Ibu Suliyem memiliki 1 orang suami yang bekerja sebagai sopir bus dan 1 anak perempuan yang sudah menikah. Ia menjadi pengrajin kain perca sudah 2 tahun sejak tahun 2019. Berdasarkan pertanyaan yang diberikan oleh peneliti maka mendapatkan jawaban dari informan sebagai berikut "menjadi pengrajin kain perca sangat menyenangkan karena dapat mengisi waktu luang selain itu juga sangat membantu keuangan untuk kebutuhan sehari-hari”. 
2. Informan 2

Ibu Kasiyati adalah seorang pengrajin kain perca di Desa Bulaksari Rt 02/ Rw 08 Kecamatan Sragen, usia ibu Kasiyati 50 tahun beragama islam, pendidikan terakhir SMK. Ibu Suliyem memiliki 1 orang suami yang bekerja sebagai kuli bahan bangunan dan memiliki 1 anak perempuan dan 1 anak lakilaki yang sudah semuanya sudah menikah. Ia menjadi pengrajin kain perca sudah 10 tahun.Berdasarkan

pertanyaan yang diberikan oleh peneliti maka mendapatkan jawaban dari informan sebagai berikut "menjadi pengrajin kain perca dilakukan karena terdesaknya ekonomi keluarga, pengeluaran kebutuhan setiap hari yang sangat banyak dan biaya pendidikan anak sekolah yang semakin mahal maka dari itu dengan menjadi pengrajin kain perca hasilnya lumayan untuk menyambung hidup".

\section{Informan 3}

Ibu Giyanti adalah seorang pengrajin kain perca di Desa Bulaksari Rt 01/ Rw 08 Kecamatan Sragen, usia ibu Giyanti 39 tahun beragama islam, pendidikan terakhir SMK. Ibu Giyanti memiliki 1 orang suami yang bekerja sebagai pedagang dan memiliki 2 anak perempuan yang keduanya masih bersekolah. Ia menjadi pengrajin kain perca baru 1 tahun. Selain menjadi pengrajin kain perca kesibukan beliau yaitu membuka warung kelontong, menjadi pengrajin kerajinan kain perca sebagai pengisi waktu luang ketika menjaga warungnya.Berdasarkan pertanyaan yang diberikan oleh peneliti maka mendapatkan jawaban dari informan sebagai berikut "selain hobi, menjadi pengrajin kain perca dilakukan karena kebutuhan sehari-hari yang belum tercukupi, maka dari itu dengan menjadi pengrajin kain perca sangat membantu untuk kebutuhan sehari-hari membantu suami”.

\section{Informan 4}

Ibu Tatik adalah seorang pengrajin kain perca di Desa Bulaksari Rt 02/ Rw 08 Kecamatan Sragen, usia ibu Tatik 55 tahun beragama islam, pendidikan terakhir SMP. Ibu Tati Sekarang sebagai single mom dikarenakan suaminya sudah meninggal, beliau memiliki 1 anak perempuan dan 1 anak laki-laki, maka dari itulah beliau mencari nafkah untuk anak-anaknya dengan menjadi pengrajin kain perca.Ia menjadi pengrajin kain perca sudah 6 tahun sejak tahun.Berdasarkan

pertanyaan yang diberikan oleh peneliti maka mendapatkan jawaban dari informan sebagai berikut "semenjak menjadi single 
mom itu saya langsung cari alternatif lain apapun itu yang penting halal, karena bakat saya di pengrajin kain perca maka saya tekuni terus demi menyekolahkan anak saya".

\section{KESIMPULAN DAN SARAN}

\section{Kesimpulan}

Berdasarkan uraian yang terdapat di atas maka dapat disimpulkan bahwa usaha industri rumah tangga (home industry) sangat membantu dan menambah pendapatan keluarga. Jawaban dari informan semua menyatakan bahwa industri rumah tangga yang dilakukan para ibu di rumah sangat membantu ekonomi keluarga, untuk kebutuhan sehari-hari dan biaya sekolah anak. Para ibu yang diwawancarai juga tidak mengatakan terpaksa karena pekerjaan yang dilakukan sesuai dengan bakat dan minat.

\section{Saran}

1. Pengembangan usaha kecil ini sebaiknya terus ditingkatkan, agar mampu menjadi contoh untuk home industry lainnya yang ada wilayah Kecamatan Sragen Kabupaten Sragen. Dengan demikian industri kecil akan hidup dan bisa membuka lapangan kerja bagi masyarakat.

2. Ada baiknya diupayakan kerja sama dengan pemerintah, dalam hal ini instansi-instansi terkait agar para ibu rumah tangga mendapatkan pelatihanpelatihan sehingga semakin meningkatkan keahlian dan daya kreatif mereka. 


\section{DAFTAR PUSTAKA}

Afrida BR. MS. 2003, Ekonomi Sumber Daya Manusia, Galia Indonesia.

Anoraga, 1996, Pengantar Bisnis

Modern, Kajian Dasar

Manajemen Perusahaan,

Pustaka Jawa, Jakarta.

Badan Pusat Statistik, Kabupaten

Lombok Timur Dalam Angka, tahun 2006.

Hadi Prayitno, 1987. Pembangunan

Ekonomi Pedesaan, LP3ES, Jakarta.

Mardikanto, 1990,Wanita dan

Keluarga, PT Tritunggal Tata

Pajar, Surakarta.

Mulyadi, S. 2003, Ekonomi Sumber

Daya Manusia Dalam

Perspektif

Pembangunan, PT Raja

Grafindo Persada.

P. Joko Subagyo. 2006, Metode

Penelitian Dalam Teori dan

Praktek, PT. Rineka Cipta , Jakarta.

Sedijoprapto. E, 1982, Tenaga Kerja Wanita Indonesia, Suatu Tinjauan Literatur, PDIN LIPI, Jakarta.
Teguh, Moh. 2005, Metodologi Penelitian Ekonomi Teori dan Aplikasi, PT. Raja Grafindo Persada, Jakarta.

Wardatul Hayati, Etos Kerja Pedagang Pindang Desa Rumbuk Kecamatan Sakra Kabupaten Lombok Timur (Tinjauan Sejarah Sosio Ekonomi), Tahun 2004, Skripsi STKIP Hamzanwadi Selong.

Wirasasmita, 1993, Laporan

Eksklusif, Baseline Survey, NTB 